\title{
ALBUMIN AS PROGNOSTIC VALUE IN HOSPITALISED PATIENTS
}

\author{
Chakrapani Alavala1, Rajendra Prasad Kathula²
}

${ }^{1}$ Associate Professor, Department of Surgery, Government Medical College, Nizamabad, Telangana. ${ }^{2}$ Associate Professor, Department of Surgery, Government Medical College, Nizamabad, Telangana.

\begin{abstract}
BACKGROUND

In cases of a pathological state, there might be a low formation of the albumin in liver or high degradation of the albumin. In either of the ways, the serum albumin will be lowered.Stress and strain is also known to cause hypoalbuminemia i.e. low serum level of albumin. Since albumin is a protein, it has to be transcribed from the genes and studies have shown that TNF-alpha supresses this transcription process. The TNF-alpha is known to increase in any inflammation and thus forms a cascade. In case of hospitalised patients, the stress and strain in pre-surgical patients and chronically hospitalised patients, the serum albumin levels are known to be less than normal. In chronically hospitalised patients, the nutritional cause can also be taken into consideration for lower serum albumin levels. Early detection of these low levels of serum albumin levels helps the surgeons and the physicians to intervene and thus cut off the progression of the disease. A sincere effort has been made in this study to understand the relations of the serum albumin level and its effects on the prognosis of the disease and outcome of the surgery if the patient is undergoing any. This study is intended to help the physician, surgeon, and general practitioners to understand and intervene in the event and thus help the patient to recover earlier and in a better way.
\end{abstract}

\section{METHODS}

Aim of the study is to estimate the mean serum albumin levels in hospitalised patients to estimate the mean serum albumin levels in patients undergoing surgery and to correlate the serum albumin levels and the prognosis of the patient. The study has been done in the Department of Surgery, Government Medical College, Nizamabad. The study was done from October 2013 to November 2014. The study is a cross-sectional study. The study is also double blinded and randomised. The study is a multi-level study. The sample size included one hundred patients. One hundred patients were identified in the Department of Surgery. The patients were either chronically ill who were hospitalised for more than three weeks or who were undergoing surgery. The serum albumin levels were estimated. In chronically hospitalised patients, the patients were divided into three groups. 1 . Serum levels less than $2 \mathrm{gm} / \mathrm{dL}$. 2. Serum levels between $2 \mathrm{~g} / \mathrm{dL}$ and $5 \mathrm{gm} / \mathrm{dL}$. 3. Serum levels more than $5 \mathrm{gm} / \mathrm{dL}$. The serum albumin levels were again estimated and the prognosis was checked in the form of non-wound healing, pain, worsening of symptoms, intrasurgical complications, postoperative sepsis and death. In each group, the necessary treatment was given in the form of nutrition supplementation in the patients whose albumin level was more than $2 \mathrm{gm} / \mathrm{dL}$ and IV albumin was given in the patients whose albumin level was less than 2 $\mathrm{gm} / \mathrm{dL}$ and were symptomatic and was observed for the prognosis. The serum albumin levels were again estimated and the prognosis was checked in the form non-wound healing, pain, worsening of symptoms, and death after three weeks since the half-life of albumin is 21 days.

\section{RESULT}

In the present study, there is a significant difference in the prognosis of the patients when the serum albumin level increases in the serum. The mean serum levels in the three groups were found to be $1.95 \mathrm{gm} / \mathrm{dL}, 2.85 \mathrm{gm} / \mathrm{dL}$, and $5.1 \mathrm{gm} / \mathrm{dL}$. In the third group, the complications were not present at all showing the significance of serum albumin levels in the prognosis and outcome of the disease.

\section{CONCLUSION}

The disease prognosis was significantly altered when the low serum albumin was altered.

\section{KEYWORDS}

Albumin, Prognosis, Hospitalized, Surgery, Patients.

HOW TO CITE THIS ARTICLE: Alavala C, Kathula RP. Albumin as prognostic value in hospitalised patients. J. Evolution Med. Dent. Sci. 2016;5(54):3607-3610, DOI: 10.14260/jemds/2016/831

\section{INTRODUCTION}

The human liver produces around fifteen grams of albumin per day under normal conditions. The human body is known to degrade about 0.5 to 0.6 grams of total body albumin in a

Financial or Other, Competing Interest: None.

Submission 06-06-2016, Peer Review 25-06-2016,

Acceptance 28-06-2016, Published 05-07-2016.

Corresponding Author:

Dr. Chakrapani Alavala

Associate Professor

Government Doctor's Quarters,

\#103, Khaleelwadi,

Nizamabad-503001.

E-mail: alavala1465@gmail.com

DOI: $10.14260 /$ jemds/2016/831 normal adult human being. Around fifty six percent of the total protein in the body is albumin. Before further discussion of the albumin levels in a human body, which is under a lot of stress and strain due to pathophysiological processes, which has been mentioned in a handful of articles. The albumin as a biochemical agent should be checked in brief. Albumin by far is the most abundant protein in the human body and as explained earlier majority of them is produced in the liver. Albumin is a simple protein as it contains only amino acids and do not contain anything else like metals, which influences the function of some proteins. The half-life of the protein albumin is around twenty one days that means around half of the total produced albumin in liver in a single day will be degraded in twenty one days. 
It has a lot of important physiological functions. Biochemically, the albumin coagulates on heating. It is easily soluble in water and it contains a net negative charge. Due to these properties, there are many physiological functions that are carried out by this amazing protein. The normal serum level that is found in the normal adult is around three to five grams per decilitre. Anything below two grams per decilitre is considered to be low. In cases of a pathological state, there might be a low formation of the albumin in liver or high degradation of the albumin. In either of the ways, the serum albumin will be lowered. ${ }^{1}$ Stress and strain is also known to cause hypoalbuminemia i.e. low serum level of albumin.2,3 Since albumin is a protein, it has to be transcribed from the genes and studies have shown that TNF-alpha supresses this transcription process. ${ }^{4,5,6}$ The TNF-alpha is known to increase in any inflammation and thus a forms a cascade. In case of hospitalised patients, the stress and strain in pre-surgical patients and chronically hospitalised patients, the serum albumin levels are known to be less than normal. In chronically hospitalised patients, the nutritional cause can also be taken into consideration for lower serum albumin levels.

Early detection of these low levels of serum albumin levels helps the surgeons and the physicians to intervene and thus cutoff the progression of the disease. ${ }^{7-11}$ A sincere effort has been made in this study to understand the relations of the serum albumin level and its effects on the prognosis of the disease and outcome of the surgery if the patient is undergoing any. This study is intended to help the physician, surgeon, and general practitioners to understand and intervene in the event and thus help the patient to recover earlier and in a better way.

\section{AIMS AND OBJECTIVES}

1. To estimate the mean serum albumin levels in hospitalised patients.

2. To estimate the mean serum albumin levels in patients undergoing surgery.

3. To correlate the serum albumin levels and the prognosis of the patient.

\section{METHODS}

The study has been done in the Department of Surgery, Government Medical College, Nizamabad, Telangana.

The study was done from October 2013 to November 2014.

The study is a cross-sectional study. The study is also double blinded and randomised. The study is a multilevel study. The sample size included one hundred patients. One hundred patients were identified in the Department of Surgery. The patients were either chronically ill who were hospitalised for more than three weeks or who were undergoing surgery.

The serum albumin levels were estimated. In chronically hospitalised patients, the patients were divided into three Groups:

1. Serum levels less than $2 \mathrm{gm} / \mathrm{dL}$.

2. Serum levels between $2 \mathrm{gm} / \mathrm{dL}$ and $5 \mathrm{gm} / \mathrm{dL}$.

3. Serum levels more than $5 \mathrm{gm} / \mathrm{dL}$.

The serum albumin levels were again estimated and the prognosis was checked in the form of non-wound healing, pain, worsening of symptoms, intrasurgical complications, postoperative sepsis, and death.
In each group, the necessary treatment was given in the form of nutrition supplementation and was observed for the prognosis.

The serum albumin levels were again estimated and the prognosis was checked in the form of non-wound healing, pain, worsening of symptoms, and death.

\section{Inclusion Criteria}

1. The patients were aged between 20 to 50 years. This was done in order to minimize the age-related bias.

2. The patients who were supposed to undergo for surgery or who were chronically hospitalised were taken for the study.

\section{Exclusion Criteria}

1. Patients who were on drugs, which were known to cause low serum albumin.

2. Chronic liver disease.

3. $<20$ years and more than $>50$ years.

\section{RESULTS}

\begin{tabular}{|c|c|}
\hline Serum Albumin Level & Number of Patients \\
\hline Group 1 $(<2 \mathrm{gm} / \mathrm{dL})$ & 56 \\
\hline Group 2 $(2-5 \mathrm{gm} / \mathrm{dL})$ & 39 \\
\hline Group $3(>5 \mathrm{gm} / \mathrm{dL})$ & 05 \\
\hline \multicolumn{2}{|c|}{ Table 1: Frequency of Patients in Each of the } \\
Divided Groups \\
\hline
\end{tabular}

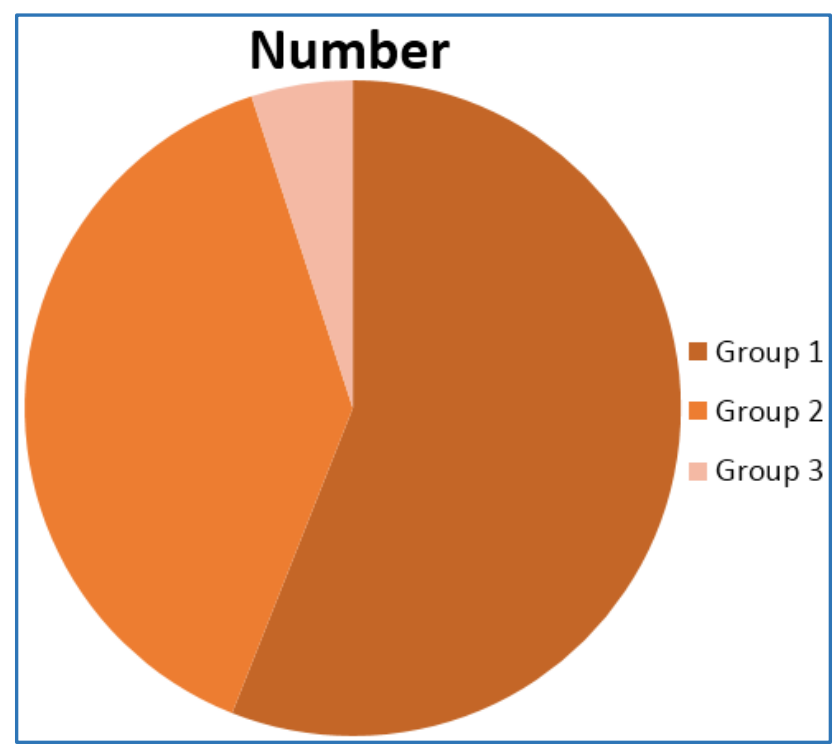

Fig. 1: Frequency of Patients

\begin{tabular}{|c|c|}
\hline Serum Albumin Level & Mean Serum Albumin Level \\
\hline Group 1 $(<2 \mathrm{gm} / \mathrm{dL})$ & $1.95 \mathrm{gm} / \mathrm{dL}$ \\
\hline Group $2(2-5 \mathrm{gm} / \mathrm{dL})$ & $2.85 \mathrm{gm} / \mathrm{dL}$ \\
\hline Group $3(>5 \mathrm{gm} / \mathrm{dL})$ & $5.1 \mathrm{gm} / \mathrm{dL}$ \\
\hline \multicolumn{2}{|c|}{ Table $2:$ Mean Serum Albumin Level } \\
in Each of the Divided Groups
\end{tabular}




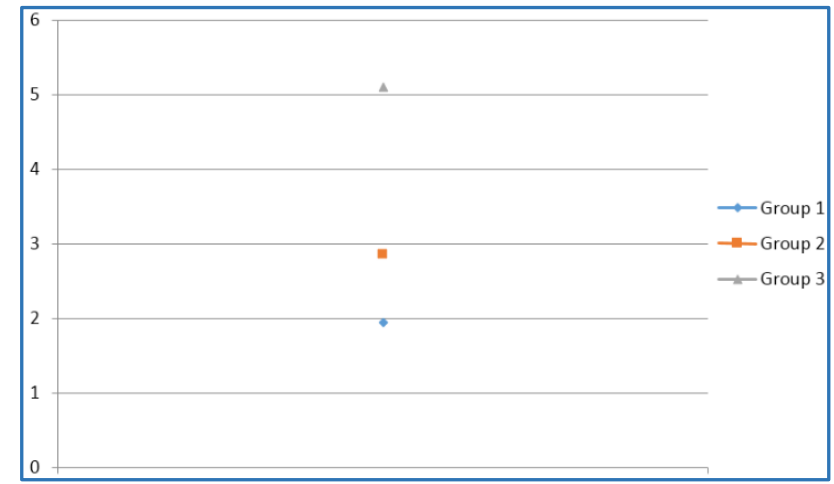

Fig. 2: Mean Serum Albumin Levels

\begin{tabular}{|c|c|}
\hline $\begin{array}{c}\text { Serum } \\
\text { Albumin Level }\end{array}$ & Prognosis \\
\hline $\begin{array}{c}\text { Group } 1 \\
(<2 \text { gm/dL })\end{array}$ & $\begin{array}{l}\text { Non-healing wounds: } 21 \\
\text { Pain: } 38 \\
\text { Worsening of symptoms: } 32 \\
\text { Intrasurgical complications: } 11 \\
\text { Postoperative sepsis: } 4 \\
\text { Death: } 8\end{array}$ \\
\hline $\begin{array}{c}\text { Group } 2 \\
(2-5 \mathrm{gm} / \mathrm{dL})\end{array}$ & $\begin{array}{l}\text { Non-healing wounds: } 09 \\
\text { Pain: } 11 \\
\text { Worsening of symptoms: } 05 \\
\text { Intrasurgical complications: } 02 \\
\text { Postoperative sepsis: } 01 \\
\text { Death: Nil }\end{array}$ \\
\hline $\begin{array}{c}\text { Group } 3 \\
(>5 \mathrm{gm} / \mathrm{dL})\end{array}$ & $\begin{array}{l}\text { All patients were posted for surgery } \\
\text { and were surgically treated without } \\
\text { any significant side effects. }\end{array}$ \\
\hline \multicolumn{2}{|c|}{$\begin{array}{c}\text { Table 3: Prognosis Table Correlation } \\
\text { to the Serum Albumin Levels }\end{array}$} \\
\hline
\end{tabular}

\begin{tabular}{|c|c|}
\hline Serum Albumin Level & Mean Serum Albumin Level \\
\hline Group $1(<2 \mathrm{gm} / \mathrm{dL})$ & $2.65 \mathrm{gm} / \mathrm{dL}$ \\
\hline Group $2(2-5 \mathrm{gm} / \mathrm{dL})$ & $4.50 \mathrm{gm} / \mathrm{dL}$ \\
\hline \multicolumn{2}{|c|}{ Table 4: Serum Albumin Levels in Post Corrected } \\
Patients After Fifteen Days of Treatment \\
\hline
\end{tabular}

\begin{tabular}{|c|c|}
\hline Serum Albumin Level & Prognosis \\
\hline $\begin{array}{c}\text { Group } 1 \\
(<2 \text { gm/dL) }\end{array}$ & $\begin{array}{l}\text { Non-healing wounds: } 02 \\
\text { Pain: } 05 \\
\text { Worsening of symptoms: } 02 \\
\text { Death: Nil }\end{array}$ \\
\hline $\begin{array}{c}\text { Group } 2 \\
(2-5 \mathrm{gm} / \mathrm{dL})\end{array}$ & $\begin{array}{l}\text { Non-healing wounds: Nil } \\
\text { Pain: } 01 \\
\text { Worsening of symptoms: Nil } \\
\text { Death: Nil }\end{array}$ \\
\hline
\end{tabular}

\begin{tabular}{|c|l|}
\hline $\begin{array}{c}\text { Serum Albumin } \\
\text { Level }\end{array}$ & \multicolumn{1}{|c|}{ Significance } \\
\hline & $\begin{array}{l}\text { Non-healing wounds: Significant } \\
(<0.052 \text { tailed }) .\end{array}$ \\
Group 1 \\
$(<2$ gm/dL $)$ & $\begin{array}{l}\text { Pain: 05 }(<0.052 \text { tailed }) . \\
\text { Worsening of symptoms: 02 }(<0.052 \\
\text { tailed }) . \text { Death: Nil }(<0.052 \text { tailed }) .\end{array}$ \\
\hline Group 2 & $\begin{array}{l}\text { Non-healing wounds: Nil }(<0.052 \\
\text { tailed }) .\end{array}$ \\
$(2-5 \mathrm{gm} / \mathrm{dL})$ & Pain: 01 $(<0.052$ tailed $)$. \\
\hline
\end{tabular}

\begin{tabular}{|l|l|}
\hline & $\begin{array}{l}\text { Worsening of symptoms: Nil }(<0.052 \\
\text { tailed). } \\
\text { Death: Nil (Not Significant). }\end{array}$ \\
\hline \multicolumn{2}{|c|}{ Table 6: Table of Significance } \\
\hline
\end{tabular}

\section{DISCUSSION}

In the present study, there is a significant difference in the prognosis of the patients when the serum albumin level increases in the serum. The mean serum levels in the three groups were found to be $1.95 \mathrm{gm} / \mathrm{dL}, 2.85 \mathrm{gm} / \mathrm{dL}$, and 5.1 $\mathrm{gm} / \mathrm{dL}$. In the third group, the complications were not present at all showing the significance of serum albumin levels in the prognosis and outcome of the disease. The disease prognosis was significantly altered when the low serum albumin was altered. Even minute difference i.e. by $1 \mathrm{gm} / \mathrm{dL}$ made a significant difference in the outcome of the disease. The study is in agreement with that of the other studies conducted by Luiz Ronaldo Alberti, Andy Petroianu ${ }^{10}$ and Donald A Redelmeier. ${ }^{11}$

Albumin acts as a transport protein and helps to transport substances, which are not affianced towards water i.e. hydrophobic agents. It acts as a binding agent and also as a carrier protein. It even helps to carry around important hydrophobic drugs, which have high pharmacodynamics values. In fact, the whole effects of some drugs depend upon the albumin level. It also helps in transport of fatty acids in lipid metabolism and bile salts and acids and help in their metabolism. Albumin is a charged particle and because of this feature normal excretion is possible in the kidney. There is an equal and opposite charge in the membranes of the kidney, which pushes albumin in an opposite direction. If the charge is hampered, then the condition called as nephrotic syndrome can be set in. This happens in a lot of children and this is not a progressive disease. It is self-limiting disease. It also is the key ingredient in forming a colloidal osmotic pressure and thus prevents serum to be evacuated in the tissue spaces and thus resulting in oedema. In cases of low levels of albumin, this may be seen.

The low levels of albumin have been blamed by many authorities to be the cause of bad outcomes of the disease and surgeries as well. The low albumin may cause oedema and thus prevent antibiotics to act on the diseased part of the body. The low albumin may also hinder the normal metabolic pathways of many drugs. All these has to be taken into consideration before the treatment schedule has to be planned. Correction of the albumin before surgeries may turn out to be miraculous for the patients especially who are undergoing surgeries. The prognosis is far better when compared to the patients with low serum albumin levels.

\section{CONCLUSION}

In the present study, there is a significant difference in the prognosis of the patients when the serum albumin level increases in the serum. The mean serum levels in the three groups were found to be $1.95 \mathrm{gm} / \mathrm{dL}, 2.85 \mathrm{gm} / \mathrm{dL}$, and 5.1 $\mathrm{gm} / \mathrm{dL}$. In the third group, the complications were not present at all showing the significance of serum albumin levels in the prognosis and outcome of the disease. The disease prognosis was significantly altered when the low serum albumin was altered. 


\section{REFERENCES}

1. http://www.psychologyafrica.com/pdf/Products/Profile \%20of\%20Mood\%20States\%20_POMS_.pdf.

2. Kalender B, Ozdemir AC, Koroglu G. Association of depression with markers of nutrition and inflammation in chronic kidney disease and end-stage renal disease. Nephron Clin Pract 2006;102(3-4):c115-21.

3. Nori US, Anup M, John IT, et al. Mortality risk factors in chronic haemodialysis patients with infective endocarditis. Nephrol Dial Transplant 2006;21(8):218490.

4. Buck M, Zhang L, Halasz NA, et al. Nuclear export of phosphorylated C/EBPbeta mediates the inhibition of albumin expression by TNF-alpha. EMBO J 2001;20(23):6712-23.

5. Chojkier M. Inhibition of albumin synthesis in chronic diseases: molecular mechanisms. J Clin Gastroenterol 2005;39(4 Suppl 2):S143-6.

6. Sandeep, Rai P. Serum albumin-a marker of surgical success. J Evid Based Med Healthc 2016;3(19):756-7. DOI: 10.18410/jebmh/2016/172.
7. Engelman DT, Adams DH, Byrne JG, et al. Impact of body mass index and albumin on morbidity and mortality after cardiac surgery. J Thorac Cardiovasc Surg 1999;118(5):866-73.

8. Galatius S, Bent-Hansen L, Wroblewski H, et al. Plasma disappearance of albumin and impact of capillary thickness in idiopathic dilated cardiomyopathy and after heart transplantation. Circulation 2000;102(3):319-25.

9. Goransson J, Jonsson 0, Lasson A. Screening of concentrations of c-reactive protein and various plasma protease inhibitors preoperatively for the prediction of postoperative complications. Eur J Surg 1998;164(2):89101.

10. Alberti LR, Petroianu A. Importance of the evaluation of serum albumin concentration in postoperative period of patients submitted to major surgeries. ABCD Arq Bras Cir Dig 2010;23(2):86-9.

11. Redelmeier DA. New thinking about postoperative hypoalbuminemia: a hypothesis of occult protein-losing enteropathy. Open Medicine 2009;3(4):e215-9. 